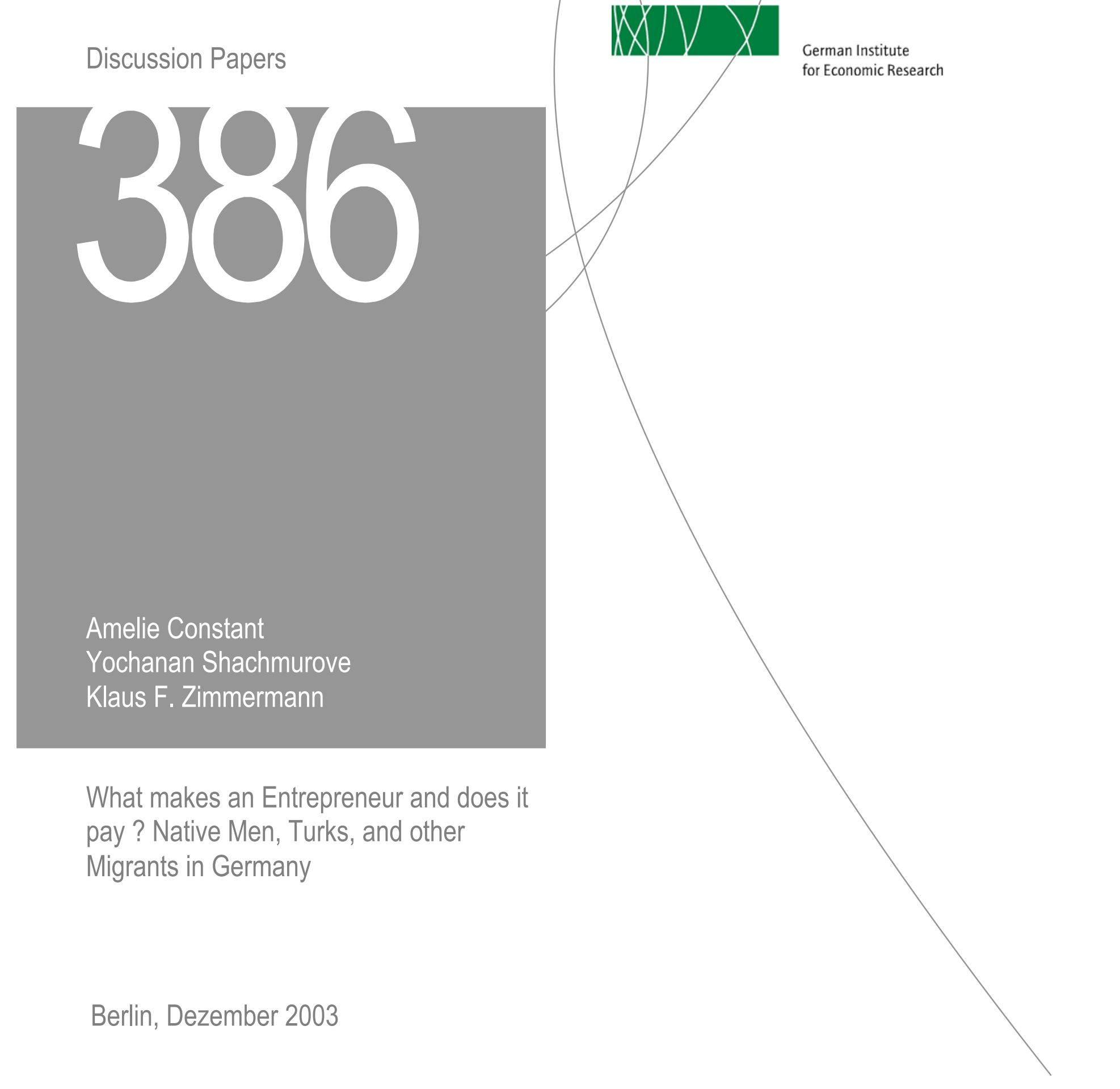


Opinions expressed in this paper are those of the author and do not necessarily reflect views of the Institute.

\section{DIW Berlin}

\section{German Institute}

for Economic Research

Königin-Luise-Str. 5

14195 Berlin,

Germany

Phone $+49-30-89789-0$

Fax +49-30-897 89-200

www.diw.de

ISSN 1619-4535 


\title{
WHAT MAKES AN ENTREPRENEUR AND DOES IT PAY? NATIVE MEN, TURKS, AND OTHER MIGRANTS IN GERMANY
}

\author{
by \\ Amelie Constant \\ IZA Bonn and University of Pennsylvania \\ constant@iza.org
}

Yochanan Shachmurove

The City College of The City University of New York and University of Pennsylvania yochanan@econ.sas.upenn.edu

and

Klaus F. Zimmermann

Bonn University, IZA, and DIW Berlin

Zimmermann@iza.org

November 2003

An earlier version of this paper was presented at the Middle Eastern Economics Association (MEEA) session of the Allied Social Science Association (ASSA) 2003 meeting in Washington, DC. We thank conference participants for many useful comments. 


\begin{abstract}
This paper focuses on the entrepreneurial endeavors of immigrants and natives in Germany. We pay closer attention to Turks, since they are the largest immigrant group with a strong entrepreneurial tradition, and the self-employed Turks in Germany represent about $70 \%$ of all Turkish entrepreneurs in the European Union. We identify the characteristics of the self-employed individuals and understand their underlying drive into selfemployment. At the same time we investigate how immigrant entrepreneurs fare in the labor market compared to natives. Employing data from the German Socioeconomic Panel 2000 release we find that the probability of self-employment increases significantly with age for all groups albeit at a decreasing rate. Among immigrants, Turks are twice as likely to choose self-employment as any other immigrant group. The age-earnings profiles of self-employed German and immigrant men are concave and surprisingly similarly shaped. While for self-employed German men hours of work and Treiman prestige scale scores increase their earnings, for self-employed immigrant men it is the longevity of the business that makes a difference. Everything else equal, the earnings of self-employed Turks are no different from the earnings of the self-employed Greeks, Italians, Spaniards, exYugoslavs, Polish or other East Europeans, including those immigrants who have become German citizens.
\end{abstract}

JEL classification: J23, M13, J24, J61, J31

Key words: Entrepreneurship; self-employment; occupational choice; immigrants; wage differentials

\title{
Corresponding author:
}

Klaus F. Zimmermann

IZA, P.O. Box 7240

D-53072 Bonn, Germany

Phone: +49 2283894200

Fax: +49 2283894210

Email: Zimmermann@iza.org 


\section{Introduction}

Entrepreneurship has been enmeshed in the American culture and is the epitome of the American dream for natives and immigrants alike. Business ownership and selfemployment, as an effective form of entrepreneurship, may be a risky venture but it has an intrinsic appeal by offering individuals the sense of independence, of higher self-worth, and life satisfaction. Entrepreneurship not only injects new dynamism into an economy but it is also of great importance for the economic prosperity and the future economic development of a country. Entrepreneurship is also a significant element in combating unemployment and welfare drain through job creation, at the very least for the selfemployed themselves. Small entrepreneurs, in particular, have contributed in the creation of revolutionary businesses and they account for the majority of the employed workers. Although entrepreneurship flourishes in the US and other "immigrants" countries, for any ethnic group, entrepreneurial activities in Germany are comparatively very low. Recently, nascent enterprises show that there is a growing business culture in Germany, and they have attracted the government's attention to ensure their boost.

The conjecture of the neoclassical human capital theory is that immigrants are a self-selected group of rational individuals who are willing to undertake risks in order to maximize their lifetime earnings and better their lives. They are characterized by a strong incentive to invest in human capital and have the inner drive to succeed in the host country's labor market. By virtue of their willingness to assume the risk of migration (both pecuniary and psychic) and undertake this new and often risky venture they become the first entrepreneurs ${ }^{1}$. Put differently, immigrants as risk takers, are more dynamic and

\footnotetext{
${ }^{1}$ By definition, an entrepreneur is an individual who organizes, operates, and assumes the risks of a business venture.
} 
inherently more prone to becoming self-employed than any other group. Self-employed individuals are working hard to fulfill their dreams, and in the process they create new jobs and opportunities. On the other hand, impediments to good jobs and to upward occupational mobility as well as unemployment and discrimination in the labor market may impel immigrants to undertake the self-employment avenue. As the literature has shown, entrepreneurship may be the only avenue for their socioeconomic advancement.

While the prevalence of self-employment among both immigrants and natives in the labor market has been researched and documented by many studies in the US, research on entrepreneurship and especially immigrant entrepreneurship in Europe, and Germany in particular, has been somewhat scant. Recent surveys on the rising literature on selfemployment in a comparative setting investigating research on Europe, the US and other immigration countries include Le (1999), Blanchflower, Oswald and Stutzer (2001), Audretsch (2002), and Audretsch, Thurik, Verheul and Wennekers (2002). They identify the role of managerial and other individual abilities, family background, occupational status, financial constraints, the nature of work, and ethnic enclaves, among other factors as relevant determinants of self-employment.

Blanchflower, Oswald and Stutzer (2001) also study latent entrepreneurship across nations and find that many people would like to be self-employed. However, this preference declines strongly with age and the probability of being self-employed is strongly increasing with age. Self-employed individuals seem to have a much higher job satisfaction than the employed. Interesting recent European studies on entrepreneurship include Taylor (2001) on the role of liquidity constraints in Britain, Pfeiffer and Reize (2000) on start-ups by previously unemployed workers in Germany and Wagner and Sternberg (2002) on the role 
of regional differences in Germany.

Empirical research on immigrant assimilation has typically found an entry wage disadvantage for immigrants, which narrows over time as immigrants "assimilate" in the host country's labor market. The rate of convergence varies among the different immigrant groups. Borjas's (1986) study on the self-employment experience of immigrants in the US shows that not only self-employed immigrants have higher annual incomes than salaried workers but they also have higher incomes than comparable self-employed natives. This is extended by Lofstrom (2002), who finds substantial differences between migrant workers and self-employed migrants in earnings and educational attainment. Entrepreneurs have a better education and earn more than other working migrants. However, education has a smaller impact on the self-employment probabilities of migrants compared to natives. The earnings of self-employed immigrants converge quickly to the earnings of the selfemployed natives.

Evans and Leighton (1989) examine the self-employment decisions of US white men. They conclude that self-employment is roughly independent of age and total labor market experience and it is more likely to be undertaken with greater access to assets. Wage experience has been found to have a much smaller return in self-employment than in wage work while experience in business has a similar return in wage work as in selfemployment. Unemployed and low-paid workers are more likely to enter self-employment. Also people who perceive that their performance depends largely on their own actions are more likely to start their own businesses.

In North America, immigrants have higher self-employment rates than natives (see Yuengert, 1995, for the US and Li, 2001, for Canada). Yuengert (1995) investigates the 
determinants of these differences. He finds that immigrants from countries with larger selfemployment sectors have higher self-employment rates. Migrants in the US cluster more in high-tax states, and find greater opportunities for tax deductions and avoidance as entrepreneurs than as salaried workers. The study is not supportive to the ethnicity enclave hypothesis. Fairlie and Meyer (1996) point out that it is of substantial importance to account for the dramatic ethnic and racial differences in self-employment across the US population. These differences prevail even if one controls for broad combinations of groups such as Asians and Hispanics and the standard tool of regressors. They find that ethnic or racial groups that emigrate from countries with high self-employment rates do not have high selfemployment rates in the US. Their results also suggest that the more economically advanced groups have a higher propensity for self-employment than the more disadvantaged migrant groups.

There is only scarce evidence about migrant entrepreneurs in Europe and especially in Germany. The findings by Clark and Drinkwater (1998) suggest that self-employment is a way out of discrimination in paid employment for immigrants in Great Britain. Wage work pays does not pay as well for ethnic minorities, compared to natives, and the wage difference has increased over time. The increase in the earnings disadvantage has been correlated with a rise in the self-employment among ethnic minorities. Although there are higher self-employment rates for non-whites than for whites, one nevertheless observes a substantive variance among the ethnic groups. Most ethnic minorities also earn less in self-employment than similar self-employed whites.

Borooah and Hart (1999) study the large differences in self-employment between Indians and black Caribbean men in Great Britain. They find that social attributes related 
to family formation are at least as important as individual characteristics. Basu (1998) finds no evidence that Asians in Britain were pushed into self-employment to avoid unemployment. Their economic success as entrepreneurs seems to be positively associated with the share of personal capital invested at the beginning and with educational qualifications.

The immigration process into Germany has been now well studied (see, for instance, Zimmermann, 1995; Constant, 1998). Germany is known to have a comparatively low rate of self-employment, but migrants exhibit an even lower rate. This is in spite of the fact that the self-employed immigrants reach earnings parity with self-employed natives and earn a premium of $30 \%$ over immigrant workers in the blue collar category (Constant, 1998). It is unclear why in a country with a relative high unemployment rate and with a relatively institutionalized labor market entry one does not observe more self-employment among immigrants. An exception is the Turks, the largest foreign ethnic group in Germany with a significant entrepreneurial tradition. In 2002, Turkish entrepreneurs in Germany were representing $69 \%$ of all Turkish entrepreneurs in the European Union (Arastirmalar and Vakfi, 2003). This suggests investigating immigrant entrepreneurship in Germany further and studying the Turkish group separately.

Therefore, we address the following questions: What factors drive self-employment in Germany among native West Germans, immigrants, and Turks? How do immigrant entrepreneurs fare in terms of earnings if compared to native Germans? Are Turks earning more because they are more self-employed? To answer these questions we analyze the economic and social determinants of the probability to become an entrepreneur and we estimate earnings regressions that gauge the assimilation effect among the self-employed. 
We control for the standard human capital variables, such as years of education, vocational training, language proficiency, and years of residence in Germany. Moreover, we add variables to account for labor market characteristics, demographics, social, and psychological ties.

For the empirical analyses we employ data from the German Socioeconomic Panel (GSOEP) 2000 release to study the factors that influence the self-employment decisions. Our results highlight the differences between Germans and immigrants both in their decision to choose self-employment and in their self-employment remuneration. For both groups we find that the probability of self-employment increases significantly with age at a decreasing rate, and Turks are twice as likely to choose self-employment as any other immigrant group. While wealth, marital status, and financial worries are important determinants for Germans they are not for immigrants. This suggests that Germans and immigrants face different labor market opportunities, and their decisions are also guided by different aspirations, motives, and life strategies. Further, we find that the age-earnings profiles of self-employed German and immigrant men are very similar and have the familiar inverted U-shape, everything else equal. Self-employed German men earn more when they work more hours per week, have higher Treiman prestige scores, and are married. On the other hand, self-employed immigrants earn more with a longer tenure in their business but they face a wage penalty for marriage. The wages of the self-employed immigrants also decrease at an increasing rate with additional years in Germany. Everything else equal, the earnings of self-employed Turks are no different from the earnings of the self-employed Greeks, Italians, Spaniards, ex-Yugoslavs, Polish or other East Europeans, including those immigrants who have become German citizens.

The rest of the paper is structured as follows: In Section 2 we provide a brief 
discussion of our data, the theoretical framework and the variables employed in the analyses. Section 3 explains the methodological approach, presents the econometric evidence and discusses the results of our analyses. We draw our concluding remarks in Section 4.

\section{Self-employed and salaried workers in Germany}

In this section, we provide an overview about the basic characteristics of self-employed and salaried workers in Germany by ethnicity. In this analysis, we concentrate on comparing the performance of the migrants with those of the West Germans and hence exclude East Germans. Even a decade after unification, East Germans do not have significant experiences with self-employment. Migrants still predominantly cluster in West Germany, and avoid the less-developed east with the much higher unemployment rates. The group of migrants studied here contains the traditional former "guestworkers," namely those from Greece, Italy, Spain, former Yugoslavia, and Turkey, who or their parents were hired especially in the early sixties to meet a demand for blue collar workers. However, we use also data on the "new" immigrants from the eighties and nineties, who came mainly from Eastern Europe, among them mostly ethnic Germans from Poland, Romania, and states from the former Soviet Union (ex-USSR). While we will compare migrants to West Germans as the relevant native reference group, we will separately investigate the Turks, who are the largest foreign ethnic group in Germany.

Section 2.1 will present the data source, discuss the major definitions of the variables used and outline basic hypotheses concerning the probability to be self-employed and the determinants of earnings among them. In section 2.2, we present and discuss the major characteristics of the sample populations and highlight the situation of 
entrepreneurship among natives and migrants in Germany.

\subsection{Data and hypotheses}

For the empirical analysis our data are drawn from the German Socioeconomic Panel (GSOEP), a nationally representative data set that has been conducted annually since 1984 and is provided by the German Institute for Economic Research (DIW Berlin). Here we use data from the GSOEP of the year 2000. This year is unique in that it includes all populations living in Germany. It also includes substantial information on labor force participation, self-employment categories, various aspects of life in Germany, and contains an assortment of attitudinal questions. More important, the 2000 data permit a more detailed analysis of the self-employed. We can, thus, differentiate between those selfemployed in agriculture, in the free-lance or professional sector, and in other self-employed categories including working for a family business (SOEP Group, 2001).

Out of the immigrant sample we extracted the Turks as a separate group. We classify as Turks all individuals who were born in Turkey or in Germany and who are Turkish nationals. Because of the idiosyncrasies of the German migration system and the German immigration law, the typical distinction between first and second generation immigrants does not apply in Germany. Immigrants who are born in Germany are not necessarily German citizens, and even if they acquire the German citizenship they are perceived as foreigners and follow separate paths in the labor market. The samples we selected for our analyses exclude those individuals who are enrolled in school, and those in the military, because military personnel follow different trajectories and may skew our estimates. Additionally, we restrict our analysis to individuals aged 18 to 64 , a prime age 
for self-employment endeavors.

Men and women usually follow different paths in the labor market. In Germany females are not fully integrated in the labor market, although the situation is somewhat changing in recent years. Consequently, we ended up with very few observations for selfemployed women. This small female sample could not justify a separate analysis, and thus, our analysis focuses on the self-employment endeavors of men in Germany in 2000.

A dummy for self-employment is constructed from a self-reported answer from the GSOEP questionnaire regarding the employment status of the individuals. It includes small and larger scale farming, free-lance processionals, working in other business, and working in family business. For all self-employed, this is their main job. We exclude selfemployment as a secondary job. The salaried workers' category includes blue collar, white collar, civil servants, and those registered as unemployed. According to our selection criteria we ended up with 2039 West Germans, 917 immigrants, and 319 Turks. Out of them, $9.9 \%$ are self-employed Germans, $4.8 \%$ are self-employed (non-Turkish) immigrants, and $6.3 \%$ are self-employed Turks.

The explanatory variables used in this paper include human capital variables (education, German language proficiency, and health) and labor market variables (Treiman prestige scores, tenure/seniority with a job/business). We also include variables that show socioeconomic attachments to Germany and to the country of origin (citizenship, own a dwelling in Germany), and other attitudinal and control variables. For immigrants we measure the effects of years of schooling and vocational training in the home country and years of schooling and vocational training in Germany separately. That way we control for differences in the initial stock of human capital (education before migration) and render immigrants' education in Germany qualitatively similar to that of Germans and among 
themselves.

The variable "speak mostly German" comes from a self-reported answer. Immigrants were asked whether they speak mostly German in their everyday life. It does not necessarily reflect superior knowledge of the language. Nonetheless, it captures the easiness immigrants have with the German language, and the image they portray to the others about being willing to integrate. Speaking the host country's language facilitates economic adaptation and improves economic performance. Self-employment is in most cases customer intensive and people oriented. We expect that those who speak mostly German will have a higher probability to go into self-employment. Health is a vital element of human capital. We include the variable of "disability limits work" as an additional variable. We hypothesize that disability and self-employment are negatively correlated.

The key variable for immigrant assimilation is the years-since-migration (YSM) variable. This variable measures the time and quality of exposure to the German environment. It measures labor market experience and human capital accumulated in Germany. For those immigrants with missing values in the YSM variable, we carefully calculated the YSM variable following a simple algorithm: if the individual is born in Germany then YSM equals the age of the individual. If the individual is born elsewhere but went to school in Germany we assigned years of migration according to whether the individual went to elementary or secondary school in Germany.

We expect that the better educated and fit individuals will go into self-employment. To the extent that education captures higher ability and allows individuals to know more and to have superior information set, we would expect that more years of schooling will push individuals into self-employment. In Germany, we would expect a strong correlation 
between education and self-employment because, especially for certain occupations, there are required educational requirements and qualifications. However, it has been often argued that self-employment is an alternative job choice for less qualified and less skilled individuals. Further, while older workers are more risk averse, we expect that selfemployment proclivity will increase with age discounted for non-linearities. Older workers have more wisdom, more experience and know-how, more financial capital, larger social milieu, and they make more prudent choices (Lecker and Shachmurove, 2001). The variable "own dwelling" is included as proxy for the individual's wealth. We expect that wealth will increase the probability of self-employment because it lessens the liquidity constraints (Taylor 1996; Evans and Leighton 1989).

Marital status plays a role in self-employment from two conflicting directions. On the one hand, marriage brings stability and, married men, it has been shown, are more productive through the division of labor and household production. Self-employment can also be a very attractive choice for married individuals because it can offer flexibility in the allocation of time between family and work. Moreover, married men can benefit from their wife's support and can count on her helping with their business as well. Self-employed married men, can also count on their wife's stable income, if she is working, as an income smoothing to go through rough times strategy. However, this is a more plausible scenario for immigrants and certain occupations. On the other hand, self-employment is considered as a risky venture and as such married men might not opt for this choice, especially when their household depends on their income.

Further, we expect that those individuals who worry about finances will have a higher probability to go into self-employment lured by the higher expected financial rewards 
from self-employment. Lastly, immigrants who feel that they do not belong in Germany will rather choose self-employment in the hopes of avoiding discrimination or alienation from the labor market. Similarly, immigrants who want to stay in Germany will also choose selfemployment as a means of becoming successful and have a business to hand down to their children.

For earnings we expect that age, education, health, and language will have a positive impact on the earnings of the self-employed men. Similarly, we expect that those self-employed men who work longer hours, and whose business is in a higher ranked prestige scale will enjoy higher earnings. Having a more stable business - captured by the variable length of time with business - reflects a serious commitment in the labor market and should have a direct advantage in earnings.

\subsection{Characteristics of the sample populations}

The differences and similarities between self-employed and salaried workers in our sample by ethnicity are highlighted in Table 1 . Across all groups self-employed men earn, on average, significantly more than their salaried counterparts. It is noteworthy that selfemployed immigrants earn more than self-employed Germans, and self-employed Turks have the highest weekly earnings among all. These statistics show that not only selfemployment is a lucrative choice for all men but for immigrants, in particular, selfemployment is a means of traversing and even annihilating the native-ethnic wage disparity. Similarly, this pattern applies to the hours of work per week and the occupational prestige score. All self-employed men work more hours per week than the salaried workers and self-employed immigrants (including the Turks) work even more hours than Germans 
do. While all self-employed enjoy a higher occupational prestige status than the salaried workers, West German men stand out by their highest Treiman occupational prestige score. West German men are followed by other immigrants, while Turks are lagging behind having the lowest occupational prestige score. It appears from this table that migrants have not been able to achieve a prestige score as high as the Germans through selfemployment, and they have to work harder. Nonetheless, they do fare quite well in terms of income.

$<<$ Table 1 about here >>

With regards to self-employment percentages, we find low percentage rates for all groups. West German men have the highest percentage (10\%) of self-employment, followed by $6 \%$ of Turks, and a low $5 \%$ by the other immigrants. On average, selfemployed men also exhibit occupational stability, tenure, and success by having their business for nearly as long as their salaried counterparts are with their employers.

Among West Germans and immigrants the self-employed are older, on average. However, the average self-employed Turk is younger than the average immigrant or West German. West Germans are the best educated group having finished, on average, at least highschool. However, with regards to education, there are not really discernible differences between self-employed and salaried workers, although the average years of schooling and vocational training is larger for the former in all groups. Among immigrants, they all have lower education than Germans, with Turks having the lowest education than the rest of the immigrant. Further, they all have some schooling before they migrated to Germany. The post-migration educational attainment of Turks and the other immigrants is higher when they are self-employed. 
Across all samples, a substantial proportion of men are married, while the share is somewhat but not largely higher for the self-employed. Turks have the largest share of married men among both groups of workers, followed by the other migrants and the Germans. Self-employed Germans have a substantially higher percentage of small children in the household than their salaried countrymen, while there is no such difference among the migrants. With respect to wealth and economic independence, $64 \%$ of the West German self-employed men own their house, followed by an impressive $41 \%$ by selfemployed immigrant men, and $20 \%$ of the self-employed Turks. Among immigrants, a higher percentage of the self-employed are German citizens than their salaried counterparts. Finally, this table shows that immigrants and Turks have been living in Germany for about a quarter of a century, indicating a rather permanent migration. The average self-employed non-Turk immigrant, in particular, has been in Germany for 30 years.

In Table 2, we portray the citizenship versus national identity and integration issues. This table clearly shows the purity of the German population and the tautology between nationality and citizenship. West Germans are 100\% German citizens and have been born in the German territory. With regards to the immigrant population in Germany, the GSOEP gives us the opportunity to look at their citizenship, their multiple nationalities, and the country they are born in. Immigrants who want to maintain their cultural and ethnic identities are often blamed as causing conflict within the host country and their poor performance is often explained through desire to maintain their identities. The summary statistics on the citizenship, nationality, feelings of belonging in Germany and desire to stay in Germany show these characteristics vary by employment status. A higher percentage 
of the self-employed, than the salaried workers, are German citizens. However, only $15 \%$ of the self-employed Turks are German citizens. Among the self-employed non German citizens, $16 \%$ of immigrants and $41 \%$ of Turks are born in Germany but have their parents' nationality. ${ }^{2}$ Interestingly enough, the self-employed have also lower intentions to apply for citizenship than the salaried workers. Whereas more of them would apply for citizenship if they were allowed to keep their parents' citizenship, still, fewer self-employed men would opt for that.

$<<$ Table 2 about here >>

The last interesting fact from this table is that, among immigrants, the self-employed feel more comfortable in Germany and want to stay in Germany compared to the salaried workers. Oddly enough, $70 \%$ of the self-employed Turks want to stay in Germany and make it their home country. With regards to worries about finances, self-employed immigrants and Turks express the least worries about their financial situation. In contrast, more self-employed West Germans worry about finances than salaried West Germans. For the rest of the categories, clearly, the self-employed worry lees than their salaried counterparts. Lastly, while all groups seem to be very concerned about hostility against immigrants in Germany, $40 \%$ of the self-employed Turks are concerned about this.

Table A1 in the Appendix shows the types of self-employment our samples are in. Overall, the majority of self-employed men own small-scale businesses of less than nine employees. More West Germans than any other group are in the self-employed farmer

\footnotetext{
${ }^{2}$ Up until recently citizenship in Germany was synonymous to nationality and was based on the "law of blood." Accordingly, individuals born outside Germany are Germans if their ancestry is German. The new law combines the existing law of blood with the "law of soil" that is the law in the US, for example. Individuals born in Germany are Germans but they have to decide by the age of 18 which nationality to keep. Naturalization rates increased by $130 \%$ in 2000 mainly due to the decreased time limit.
} 
category. The vast majority of self-employed men across all groups lie in the "other business" category employing. This category includes retail and restaurants. Turks dominate this category, especially in the small scale business. About $24 \%$ of the West Germans are in the free-lance professional category followed by $19 \%$ of immigrants. This category includes lawyers, doctors, teachers, and the hi-tech computer category. We are amazed not to find any Turks in this category. On the other hand, more Turks than any other group work in the family business. This indicates that Turks rely more on kinship and familial support when they open a new business, in sharp contrast to the other immigrants.

\section{Econometric method and results}

\subsection{Methodology}

In our methodological framework, the unit of the analysis is the individual. In the first part of the econometric analysis we model the choice behavior of workers as a binomial logit. We assume that individual agents in the host country are facing two alternatives: the option of becoming self-employed versus the option of being a wage or salary worker. Individual agents maximize utility gained from the attributes of that choice. We assume that utility depends on the corresponding financial rewards of the choice. If the expected wages from self-employment exceed the expected wages from other types of employment, the individual workers choose to become self-employed. Such behavior is described in probabilistic terms. We estimate the probability of becoming self-employed based on values of a set of explanatory variables. This probability is not directly observed. Logistic regression model is an advantageous technique for estimating models with a binary dependent variable. Our dependent variable $Y$ is a categorical variable that takes the value 
of one if an individual is self-employed and the value of zero otherwise.

The choice probability, assuming a logistic distribution, is:

$$
P(Y=1 \mid X)=\frac{e^{\beta^{\prime} x_{i}}}{1+e^{\beta^{\prime} x_{i}}}=\Lambda\left(\beta^{\prime} x\right)
$$

where $I$ indexes the individuals. The parameters $\beta$ reflect the impact of changes in $X$ on the probability that $Y=1 .{ }^{3}$ The virtue of equation (1) is that its inverse (the log odds ration) has the following closed form:

$$
\ln \left(\frac{P}{1-P}\right)=\beta^{\prime} x
$$

The explanatory variables in $X$ consist of a set of human capital (such as years of schooling and vocational training, German language proficiency, and health), individual specific characteristics, and socioeconomic characteristics. We include variables that measure economic, social, and psychological attachments to Germany, as well as attitudinal variables. All these independent variables are expected to affect the individual's probability to become an entrepreneur. The probability of becoming self-employed is also a function of age and its square and of the Years-since-Migration (YSM) and its square. YSM is the key instrument on the analysis on immigrants. The model is solved with maximum likelihood estimation. Since likelihood equations are non-linear in the parameters $\beta$ an iterative algorithm is used for the maximization of the likelihood function. The resulting estimates, b, are asymptotically unbiased, consistent, normal, and efficient. Finally, the

${ }^{3}$ The parameters of the logit are not necessarily the marginal effects, but vary with the values of $x$ as: $\theta E[y] / \theta x=\Lambda(\beta x)[1-\Lambda(\beta x)] \beta$ or $\theta E[y] / \theta x=P(Y=1)[1-P(Y=1)] \beta$. This is why the odds ratio is used. In essence, the estimated coefficient $b$ represents the change in log odds for a unit increase in the independent variable.

${ }^{4}$ The odds are the ratio of two probabilities for any mutually exclusive events or $\mathrm{P} /(1-\mathrm{P})$. 
following equation

$$
P(Y=1)=\frac{1}{1+e^{-b^{\prime} x}}
$$

gives the predicted probabilities of self-employment for the representative individual in each ethnic group. The actual probabilities can be evaluated either at the sample means of the $X_{\mathrm{s}}$ or at specific values of the $X_{\mathrm{s}}$. The results from this exercise will give us insights into the self-selection process and the role of the different characteristics of choosing the entrepreneurial avenue. We expect that individuals who are more educated, have more years of residence in Germany, have good health, are married, and do not come from socialist economies will have a higher probability of becoming entrepreneurs.

Next, we operationalize the earnings assimilation of entrepreneurs in Germany. The estimation of earnings is given by the following structural equation (Mincerian wage equation):

$$
\ln W_{j}=X_{2 j}^{\prime} \beta_{2}+Y S M_{j}^{\prime} Y_{2}+\epsilon_{j}
$$

with $j$ denoting the number of observations. The dependent variable is the natural logarithm of gross weekly income, and $X$ is a vector of socioeconomic characteristics similar to those specified in the logistic analysis but fine tuned to identify earnings. For example, here we include labor market characteristics and labor market structures. Earnings are a function of the same socioeconomic characteristics of all groups with additional variables added to explain the earnings of immigrants. Additional explanatory variables affecting the earnings of immigrants only are years of education before migration and categorical variables for language capability. The vector YSM stands for the key variable in the assimilation estimation, years of residence one has accumulated in Germany. We include the square 
of YSM to capture any diminishing returns on earnings. The YSM coefficients in $\mathrm{Y}_{2}$ measure the experience-aging effect on earnings. For immigrants, the estimates of $\mathrm{Y}_{2}$ along with the coefficient on age - measure the pure assimilation effect. Our prediction is that the earnings of immigrants increase with additional years-since-migration to a point where they reach those of Germans. Lastly, $\epsilon_{j}$ is the stochastic error assumed to be independent of the $X_{\mathrm{s}}$.

Following the premises of the neoclassical human capital theory, we expect that the more educated immigrants will have higher earnings than comparable natives. Similarly, we expect the earnings profiles with respect to age to have an inverted U-shape. If selfemployed workers are positively self-selected for their inner drive to be independently successful and to climb the socioeconomic ladder, they should also earn significantly higher wages, all else equal. We estimate both the logit and wage regressions on three groups of self-employed men in Germany, namely, the West Germans, the immigrants, and the Turks. We believe that each group is cohesive and homogeneous and is governed by similar experiences. Yet, there are distinct socio-economic and labor market differences among groups that warrant separate analyses. The heterogeneity among the groups under study is subject to very different influences by the business cycle, government policies, institutional frameworks, and demographics.

\subsection{Estimation results}

In Table 3 we present the results of the binomial logit regression estimation on the probability of self-employment for the respective samples. In this exercise we estimated logits for West Germans and immigrants separately. Due to the small number of 
observations for Turks we combined all immigrant groups in one sample and created a dummy variable for Turks. For each group, we present the coefficient estimates with the standard errors in parenthesis underneath; the asterisk denotes the significance level at $5 \%$ in a two-tail test. In the adjacent column we present the odds ratios.

$<<$ Table 3 about here $>$

Across all groups, the probability to become self-employed increases significantly with age at a decreasing rate. These results, further, show a stable age profile that is very similar between Germans and immigrants. Surprisingly, education is not a significant determinant of the self-employment propensity for West German men. One explanation could be that the years of schooling between self-employed and salaried Germans are the same. An additional explanation is that Germans choose self-employment for the financial rewards and not as a means to overcome educational frustrations from paid employment.

For West Germans, the probability to choose self-employment decreases for those in poor health and for married men. We are surprised to find that marriage is a deterrent to entrepreneurship for German men. According to theory and empirical results for other countries, women subsidize their husbands' jobs. That is, men rely on their wives for a steady income if they work outside of the family business and count on their helping directly in the business. We believe that this result can be explained by the more traditional - in the sense of the "breadwinner" ideology - German family. That is, West German women have a long tradition of staying home and taking care of the children and the household and rely on their husbands to provide for the household. Consequently, selfemployment, which can be a risky venture, would not be an optimal choice for German men. The rest of the results are as expected for Germans. Owing real estate increases the 
probability of self-employment by $54 \%$. Lastly, for those Germans who expressed financial worries, the odds to choose self-employment double.

Among immigrant men, the odds of becoming self-employed almost double for Turks. A possible explanation that we offer is that Turks are more entrepreneurial than the rest of the immigrants in our sample. Alternatively, entrepreneurial choice for Turks could disguise a choice against structural barriers, limited employment choices, and discrimination in the labor market. Immigrants often experience social exclusion, and entrepreneurship maybe a way of cutting through it and being accepted. Although the years since migration variable is not significant, the signs show that during the beginning of their immigrant career the odds of choosing self-employment decrease with time in Germany. However, after immigrants have stayed in Germany for a longer time they will rather choose self-employment than a salaried job. Lastly, none of the rest of the variables are significant determinants of self-employment for immigrant men.

In Table 4 we present the results of the human capital earnings regression for the respective samples for the self-employed. We estimate Mincerian log weekly wage regressions for West Germans, and immigrants separately. For each group we present the coefficient estimates with the standard errors in parenthesis underneath. The asterisk denotes the significance level at $5 \%$ in a two tail test.

$<<$ Table 4 about here>>

As expected, we find that the age-earnings profile for all samples is concave. Amazingly, the age coefficients are very similar for both groups. Education does not have a significant effect on the wages of self-employed Germans. This is consistent with the conjecture that once men are into self-employment education is irrelevant for their 
earnings. While more education makes individuals more capable and well-rounded the stereotypical returns to education scenario for the paid employment does not apply here. With respect to the rest of the predictors, we find longer hours of work per week and high Treiman occupational scores significantly increase the wages of self-employed Germans. Lastly, married West German self-employed men earn 21\% more than other men. It appears that the breadwinner model of the German family allows men to focus more in their business and drives them to be more determined to succeed with their business, once they have chosen this avenue.

Turning to the analysis for the immigrants, it is interesting that the intercept is a lot higher than that for the Germans. Our results show that both age and YSM have a significant impact on the earnings of self-employed immigrant men. However, the YSM exhibits a U-shaped profile indicating a slightly decreasing pattern with additional YSM. The long tenure with the business is significant and positive showing that those immigrants who manage to have a stable business are faring well. Marriage, to our surprise, has a negative coefficient. All else equal, the earnings of self-employed immigrants in our sample decrease by $36 \%$ when they are married, as opposed to being single, divorced, or widowers. A plausible explanation for this puzzling finding lies in the different structure of the immigrant families. If immigrant wives help with the family business then this might have a confounding effect on earnings because the earnings are shared through family work. In addition, if immigrant wives work, men can potentially count on their wives' incomes. Controlling for socioeconomic and labor market characteristics, we find that the wages of Turkish self-employed men are no different from any other immigrant group.

As the figure in the appendix shows, the wage structures of the three groups of men 
under study are very different. For example, immigrants and especially Turks are lacking the upper tail of the income distribution. Clearly, West German men dominate with higher wages. Notice that the analysis for the immigrants is based on the self-employed only because the purpose of the paper is to see how Turks fare in the labor market as selfemployed, in reference to the other self-employed immigrants.

$$
\text { <<Figure } 1 \text { about here>> }
$$

\section{Conclusions}

In this paper we initiated the analysis of the entrepreneurial behavior and monetary success of two distinct populations in Germany while focusing on immigrants from Turkey the largest immigrant group in Germany. In particular, we estimated the probability of individual men to choose self-employment as opposed to salaried jobs for Germans and immigrants, and we estimated the earnings of the self-employed trying to find the determinants of success in self-employment. Based on the latest release of the GSOEP, we find that, unlike all other immigrant countries (for example the US with a booming entrepreneurial sector and where immigrant entrepreneurship flourishes), Germany's selfemployment sector occupies a very low percentage. While self-employed Germans are $10 \%$ of the male labor force, immigrant men's self-employment is at a low $5 \%$. The empirical results presented in this paper suggest that, Germans and immigrants are drawn into the world of business ownership by different motives. Overall, for all groups the probability of self-employment increases significantly with age albeit at a discounting rate. For West German men the probability of self-employment decreases with marriage and poor health but increases with owning real estate. Also, West German men who 
acknowledge having serious worries about financial matters have a higher probability of choosing the self-employment avenue. Among immigrants, Turks are twice as likely to choose self-employment as any other immigrant group.

Our human capital wage regression analysis revealed that age is a crucial determinant of earnings for both groups and the profiles are very similar. Self-employed German men earn more when they work more and their business ranks higher in the Treiman prestige scale. Moreover, marriage increases the earnings of self-employed Germans by $21 \%$. For immigrants, earnings increase significantly when they are longer with the business, indicating a powerful effect through the stability and longevity of their business.

In contrast, the earnings of self-employed immigrants decrease with additional time in Germany and with marriage. Looking at all the ethnic groups that compose the immigrants in our sample, no group stands out in the self-employment profession. Everything else equal, the earnings of self-employed Turks are no different from the earnings of the self-employed Greeks, Italians, Spaniards, ex-Yugoslavs, Polish or other East Europeans, including those immigrants who have become German citizens.

\section{References}

Arastirmalar, Türkiye, and Merkezi Vakfi, 2003, Die Wirtschaftskraft der türkischen Selbständigen, Essen: Stiftung Zentrum für Türkeistudien.

Audretsch, David B., 2002, Entrepreneurship: A Survey of the Literature, paper prepared for the European Commission, Enterprise Directorate General, mimeo. 
Audretsch, David B., Roy Thurik, Ingrid Verheul and Sander Wennekers, 2002, Entrepreneurship: Determinants and Policy in a European-U.S. Comparison, Boston: Kluwer Academic Publishers.

Basu, Anuradha, 1998, "An Exploration of Entrepreneurial Activity among Asian Small Businesses in Britain," Small Business Economics 10 (4), 313-326.

Blanchflower, David G., Andrew Oswald and Alois Stutzer, 2001, "Latent Entrepreneurship Across Nations," European Economic Review 45, 680-691.

Borooah, Vani K. and Mark Hart, 1999, "Factors Affecting Self-Employment among Indian and Black Caribbean Men in Britain," Small Business Economics 13 (2), 111-129.

Borjas, George J., 1986, "The Self-Employment Experience of Immigrants," Journal of Human Resources 21 (4), 485-506.

Clark, Kenneth and Stephen Drinkwater, 1998, "Ethnicity and Self-employment in Britain," Oxford Bulletin of Economics and Statistics 60 (3), 383-407.

Constant, Amelie, 1998, The Earnings of Male and Female Guestworkers and Their Assimilation into the German Labor Market: A Panel Study 1984-1993, Ph.D. Dissertation: Vanderbilt University.

Evans, David S. and Linda S. Leighton, 1989, "Some Empirical Aspects of Entrepreneurship," American Economic Review 79 (3), 519-535.

Fairlie, Robert W. and Bruce D. Meyer, 1996, "Ethnic and Racial Self-employment Differences and Possible Explanations," Journal of Human Resources 31 (4), 757-793.

Le, Anh T., 1999, "Empirical Studies of Self-Employment," Journal of Economic Surveys 13 (4), 381-416. 
Lecker, Tikva, and Shachmurove, Yochanan, (1999) "Immigration and Socioeconomic Gaps: Theory and Applications," Applied Economics 31, 539-549.

Li, Peter S., 2001, "Immigrants' Propensity to Self-employment: Evidence from Canada," International Migration Review 35, 1106-1128.

Lofstrom, Magnus, 2002, "Labor Market Assimilation and the Self-employment Decision of Immigrant Entrepreneurs," Journal of Population Economics 15, 83-114.

Pfeiffer, Friedhelm, and Frank Reize, 2000, "Business Start-ups by the Unemployed - an Econometric Analysis Based on Firm Data," Labour Economics 7, 629-663.

SOEP Group, 2001, "The German Socio-Economic Panel (GSOEP) after more than 15 years - Overview," Quarterly Journal of Economic Research 70, 7-14.

Taylor, Mark P., 1996, "Earnings, Independence or Unemployment: Why Become SelfEmployed?", Oxford Bulletin of Economics and Statistics 58 (3), 253-266.

Taylor, Mark P., 2001, "Self-Employment and Windfall Gains in Britain: Evidence from Panel Data," Economica 68, 539-565.

Wagner, Joachim and Rolf Sternberg, 2002, "Personal and Regional Determinants of Entrepreneurial Activities: Empirical Evidence from the REM Germany," Institute for the Study of Labor, IZA Discussion Paper No. 624.

Yuengert, Andrew M., 1995, “Testing Hypotheses of Immigrant Self-Employment," Journal of Human Resources 30 (1), 194-204.

Zimmermann, Klaus F., 1995, "Tackling the European Migration Problem," Journal of Economic Perspectives 9, 45-62. 
TABLE 1. SELECTED CHARACTERISTICS ON SELF-EMPLOYED AND SALARIED WORKERS BY ETHNICITY

\begin{tabular}{|c|c|c|c|c|c|c|}
\hline & \multicolumn{2}{|c|}{ WEST GERMANS } & \multicolumn{2}{|c|}{ IMMIGRANTS* } & \multicolumn{2}{|c|}{ TURKS } \\
\hline & $\begin{array}{l}\text { Self- } \\
\text { employed }\end{array}$ & $\begin{array}{l}\text { Salaried } \\
\text { Workers }\end{array}$ & $\begin{array}{l}\text { Self- } \\
\text { employed }\end{array}$ & $\begin{array}{l}\text { Salaried } \\
\text { Workers }\end{array}$ & $\begin{array}{l}\text { Self- } \\
\text { employed }\end{array}$ & $\begin{array}{l}\text { Salaried } \\
\text { Workers }\end{array}$ \\
\hline Weekly wages (in DM) ${ }^{1}$ & $1874.63^{b}$ & $1394.04^{b}$ & $1972.84^{\mathrm{b}}$ & $1115.38^{b}$ & $2116.94^{b}$ & 1081.68 \\
\hline Average weekly hours of work ${ }^{1}$ & 50.64 & 42.56 & 52.00 & 42.22 & 52.69 & 40.70 \\
\hline Treiman Occupational Prestige Score ${ }^{1}$ & 47.28 & 43.68 & 44.84 & 38.01 & 39.15 & 35.13 \\
\hline Length of time with firm/business ${ }^{1}$ & 11 & 12 & 9 & 9 & 7 & 10 \\
\hline Age in years & 43.63 & 42.01 & 43.25 & 40.63 & 37.05 & 40.12 \\
\hline $\begin{array}{l}\text { Years of schooling \& vocational } \\
\text { training in Germany }\end{array}$ & $12.87^{\mathrm{a}}$ & $12.37^{\mathrm{a}}$ & $7.83^{\mathrm{a}}$ & $6.68^{a}$ & 4.90 & 4.15 \\
\hline $\begin{array}{l}\text { Years of schooling \& vocational } \\
\text { training before migration }\end{array}$ & - & - & $3.82^{\mathrm{a}}$ & $4.17^{\mathrm{a}}$ & 5.30 & 5.15 \\
\hline Speak German all the time (in \%) & - & - & 23 & 29 & 45 & 23 \\
\hline Disability limits work (in \%) & 10 & 13 & 9 & 14 & 0 & 14 \\
\hline Years-since-Migration & - & - & 30.07 & 25.64 & 23 & 24.29 \\
\hline Married (in \%) & 67 & 65 & 73 & 70 & 80 & 79 \\
\hline Single (in \%) & 23 & 28 & 20 & 24 & 15 & 17 \\
\hline Children in $\mathrm{HH}<16$ yrs old (in \%) & 47 & 35 & 41 & 41 & 55 & 59 \\
\hline Own dwelling in Germany (in \%) & 65 & 54 & 41 & 27 & 20 & 20 \\
\hline German Citizen (in \%) & 100 & 100 & 57 & 53 & 15 & 11 \\
\hline ex-Yugoslavs & - & - & 36 & 46 & - & - \\
\hline EU nationals & - & - & 39 & 38 & - & - \\
\hline non-EU nationals & - & - & 25 & 16 & - & - \\
\hline Number of Observations & 202 & 1837 & 44 & 873 & 20 & 299 \\
\hline Self-employed as $\%$ of total group obs & 10 & - & 5 & - & 6 & - \\
\hline${ }^{1}$ Number of Obs with $>0$ income & 202 & 1492 & 44 & 668 & 20 & 206 \\
\hline
\end{tabular}

Note: * Includes Greeks, Italians, Spaniards, ex-Yugoslavs, and other Eastern Europeans

${ }^{a}$ The analysis of independent-samples t-test revealed a significant difference between West Germans and the other samples

${ }^{\mathrm{b}}$ The analysis of independent-samples t-test failed to reveal a significant difference between West Germans and the other samples

Source: Own calculations from GSOEP 2000 
TABLE 2. SELECTED CHARACTERISTICS ON CITIZENSHIP AND ATTITUDINAL VARIABLES BY EMPLOYMENT STATUS AND ETHNICITY: MEN IN GERMANY IN 2000

\begin{tabular}{|c|c|c|c|c|c|c|}
\hline & \multicolumn{2}{|c|}{ WEST GERMANS } & \multicolumn{2}{|c|}{ IMMIGRANTS* } & \multicolumn{2}{|c|}{ TURKS } \\
\hline & $\begin{array}{c}\text { Self- } \\
\text { employed }\end{array}$ & $\begin{array}{l}\text { Salaried } \\
\text { Workers }\end{array}$ & $\begin{array}{c}\text { Self- } \\
\text { employed }\end{array}$ & $\begin{array}{l}\text { Salaried } \\
\text { Workers }\end{array}$ & $\begin{array}{c}\text { Self- } \\
\text { employed }\end{array}$ & $\begin{array}{l}\text { Salaried } \\
\text { Workers }\end{array}$ \\
\hline German Citizen (in \%) & 100 & 100 & 57 & 53 & 15 & 11 \\
\hline Born in Germany (in \%) ${ }^{1}$ & 100 & 100 & 44 & 47 & 0 & 15 \\
\hline Have $2^{\text {nd }}$ Nationality (in \%) ${ }^{1}$ & - & - & 16 & 12 & 0 & 15 \\
\hline Not born in Germany (in \%) & - & - & 56 & 53 & 100 & 85 \\
\hline Not a German Citizen (in \%) & - & - & 43 & 47 & 85 & 89 \\
\hline Born in Germany (in \%) ${ }^{3}$ & - & - & 16 & 25 & 41 & 18 \\
\hline Apply for German Citizenship (\%) ${ }^{3}$ & - & - & 16 & 23 & 29 & 31 \\
\hline Apply if allowed dual Citizenship (\%) ${ }^{3}$ & - & - & 42 & 45 & 47 & 62 \\
\hline Feel that do not Belong (in \%) & - & - & 16 & 26 & 35 & 48 \\
\hline Want to stay in Germany (in \%) & - & - & 30 & 46 & 70 & 63 \\
\hline Worries about finances (in \%) & 20 & 13 & 18 & 22 & 35 & 37 \\
\hline Worries about immigration to Germany (in \%) & 29 & 35 & 18 & 19 & 20 & 22 \\
\hline Worries about hostility against foreigners (in\%) & 21 & 25 & 14 & 24 & 40 & 36 \\
\hline Number of Observations & 202 & 1837 & 44 & 873 & 20 & 299 \\
\hline Number of Observations & \multicolumn{2}{|c|}{2039} & \multicolumn{2}{|c|}{917} & \multicolumn{2}{|c|}{319} \\
\hline
\end{tabular}

Note: * Includes Greeks, Italians, Spaniards, ex-Yugoslavs, and other Eastern Europeans

${ }^{1}$ Based on the German Citizens

${ }^{2}$ Based on the German Citizens who are not born in Germany

${ }^{3}$ Based on the NON German Citizens

Source: Own calculations from GSOEP 2000 
TABLE 3. ESTIMATION RESULTS ON THE PROBABILITY OF SELF-EMPLOYMENT: IMMIGRANT AND NATIVE MEN IN GERMANY IN 2000

\begin{tabular}{|c|c|c|c|c|}
\hline \multirow[b]{2}{*}{ Parameters } & \multicolumn{2}{|c|}{ WEST GERMANS } & \multicolumn{2}{|c|}{ ALL IMMIGRANTS } \\
\hline & $\begin{array}{l}\text { Coefficient } \\
\text { (St. Error) }\end{array}$ & Odds Ratio & $\begin{array}{l}\text { Coefficient } \\
\text { (St. Error) }\end{array}$ & Odds Ratio \\
\hline Constant & $\begin{array}{c}-10.412^{*} \\
(1.391)\end{array}$ & - & $\begin{array}{l}-9.635^{\star} \\
(2.082)\end{array}$ & - \\
\hline Age & $\begin{array}{l}0.348^{*} \\
(0.064)\end{array}$ & 1.417 & $\begin{array}{c}0.331^{*} \\
(0.103)\end{array}$ & 1.393 \\
\hline $\mathrm{Age}^{2}$ & $\begin{array}{l}-0.004^{*} \\
(0.001)\end{array}$ & 0.996 & $\begin{array}{l}-0.0038^{*} \\
(0.0012)\end{array}$ & 0.996 \\
\hline Years-since-Migration & - & - & $\begin{array}{l}-0.030 \\
(0.038)\end{array}$ & 0.970 \\
\hline Years-since-Migration² & - & - & $\begin{array}{c}0.0007 \\
(0.0006)\end{array}$ & 1.001 \\
\hline Education in Germany & $\begin{array}{c}0.044 \\
(0.028)\end{array}$ & 1.045 & $\begin{array}{c}0.045 \\
(0.033)\end{array}$ & 1.046 \\
\hline Education before Migration & - & - & $\begin{array}{c}0.038 \\
(0.058)\end{array}$ & 1.039 \\
\hline Speaking mostly German & - & - & $\begin{array}{c}0.288 \\
(0.328)\end{array}$ & 1.333 \\
\hline Disability limits work & $\begin{array}{l}-0.515^{\star} \\
(0.260)\end{array}$ & 0.597 & $\begin{array}{l}-0.869 \\
(0.541)\end{array}$ & 0.419 \\
\hline Married & $\begin{array}{l}-0.413^{*} \\
(0.181)\end{array}$ & 0.661 & $\begin{array}{r}-0.210 \\
(0.337)\end{array}$ & 0.811 \\
\hline Own dwelling & $\begin{array}{c}0.432^{*} \\
(0.166)\end{array}$ & 1.54 & $\begin{array}{c}0.221 \\
(0.292)\end{array}$ & 1.247 \\
\hline Financial worries & $\begin{array}{l}0.672^{*} \\
(0.202)\end{array}$ & 1.959 & $\begin{array}{c}0.049 \\
(0.321)\end{array}$ & 1.050 \\
\hline Feel not belong in Germany & - & - & $\begin{array}{l}-0.397 \\
(0.328)\end{array}$ & 0.673 \\
\hline Want to stay in Germany & - & - & $\begin{array}{l}-0.266 \\
(0.329)\end{array}$ & 0.766 \\
\hline Turk & - & - & $\begin{array}{l}0.602^{*} \\
(0.301)\end{array}$ & 1.825 \\
\hline $\begin{array}{l}\text { AIC } \\
\text { Likelihood Ratio } \\
\mathrm{N}\end{array}$ & & & & \\
\hline
\end{tabular}


TABLE 4. WAGE REGRESSION ESTIMATION RESULTS: SELF-EMPLOYED MEN IN GERMANY IN 2000

\begin{tabular}{|c|c|c|}
\hline & WEST GERMANS & ALL IMMIGRANTS \\
\hline Parameters & $\begin{array}{l}\text { Coefficient } \\
\text { (St. Error) }\end{array}$ & $\begin{array}{l}\text { Coefficient } \\
\text { (St. Error) }\end{array}$ \\
\hline Constant & $\begin{array}{l}2.552^{*} \\
(0.747)\end{array}$ & $\begin{array}{l}4.731^{*} \\
(1.219)\end{array}$ \\
\hline Age & $\begin{array}{l}0.152^{*} \\
(0.037)\end{array}$ & $\begin{array}{l}0.145^{*} \\
(0.058)\end{array}$ \\
\hline $\mathrm{Age}^{2}$ & $\begin{array}{l}-0.002^{*} \\
(0.0004)\end{array}$ & $\begin{array}{l}-0.002^{*} \\
(0.001)\end{array}$ \\
\hline Years-since-Migration & - & $\begin{array}{l}-0.043^{*} \\
(0.019)\end{array}$ \\
\hline Years-since-Migration ${ }^{2}$ & - & $\begin{array}{l}0.001^{*} \\
(0.000)\end{array}$ \\
\hline Education in Germany & $\begin{array}{c}0.015 \\
(0.021)\end{array}$ & $\begin{array}{l}-0.030 \\
(0.019)\end{array}$ \\
\hline Education before Migration & - & $\begin{array}{c}0.001 \\
(0.025)\end{array}$ \\
\hline Speak Mostly German & - & $\begin{array}{c}0.020 \\
(0.155)\end{array}$ \\
\hline Disability Limits Work & $\begin{array}{c}0.046 \\
(0.150)\end{array}$ & $\begin{array}{l}-0.115 \\
(0.315)\end{array}$ \\
\hline Hours per week & $\begin{array}{l}0.010^{*} \\
(0.003)\end{array}$ & $\begin{array}{c}0.006 \\
(0.005)\end{array}$ \\
\hline Length of time with business & $\begin{array}{c}0.002 \\
(0.006)\end{array}$ & $\begin{array}{l}0.034^{*} \\
(0.011)\end{array}$ \\
\hline Treiman Prestige Score & $\begin{array}{l}0.012^{*} \\
(0.004)\end{array}$ & $\begin{array}{l}0.008 \\
(0.006)\end{array}$ \\
\hline Married & $\begin{array}{l}0.208^{*} \\
(0.103)\end{array}$ & $\begin{array}{l}-0.357^{*} \\
(0.159)\end{array}$ \\
\hline Turk & - & $\begin{array}{c}0.075 \\
(0.149)\end{array}$ \\
\hline Dependent Mean (Log weekly wages) & 7.318 & 7.456 \\
\hline F Value & 10.42 & 3.11 \\
\hline R Squared & 0.302 & 0.447 \\
\hline$N$ & 202 & 64 \\
\hline
\end{tabular}




\section{APPENDIX}

TABLE A1. TYPE OF SELF-EMPLOYMENT BY ETHNICITY

\begin{tabular}{|c|c|c|c|}
\hline & $\begin{array}{c}\text { WEST } \\
\text { GERMANS }\end{array}$ & IMMIGRANTS* & TURKS \\
\hline \multicolumn{4}{|l|}{ Independent Farmer } \\
\hline \multicolumn{3}{|l|}{ Free-Lance Professional } & - \\
\hline with $<9$ employees & $21.78 \%$ & $19.45 \%$ & - \\
\hline with $>=9$ employees & $1.98 \%$ & - & - \\
\hline \multicolumn{4}{|l|}{ Other Business } \\
\hline with $<9$ employees & $58.42 \%$ & $68.18 \%$ & $85 \%$ \\
\hline with $>=9$ employees & $4.46 \%$ & $6.82 \%$ & $5 \%$ \\
\hline Work in Family Business & $1.98 \%$ & - & $10 \%$ \\
\hline Number of Observations & 202 & 44 & 20 \\
\hline \multicolumn{4}{|c|}{$\begin{array}{l}\text { Note: * Includes Greeks, Italians, Spaniards, ex-Yugoslavs, and other Eastern Europeans } \\
\text { a The analysis of independent-samples t-test revealed a significant difference between West Germans } \\
\text { and the other samples } \\
\text { b The analysis of independent-samples t-test failed to reveal a significant difference between West } \\
\text { Germans and the other samples }\end{array}$} \\
\hline
\end{tabular}




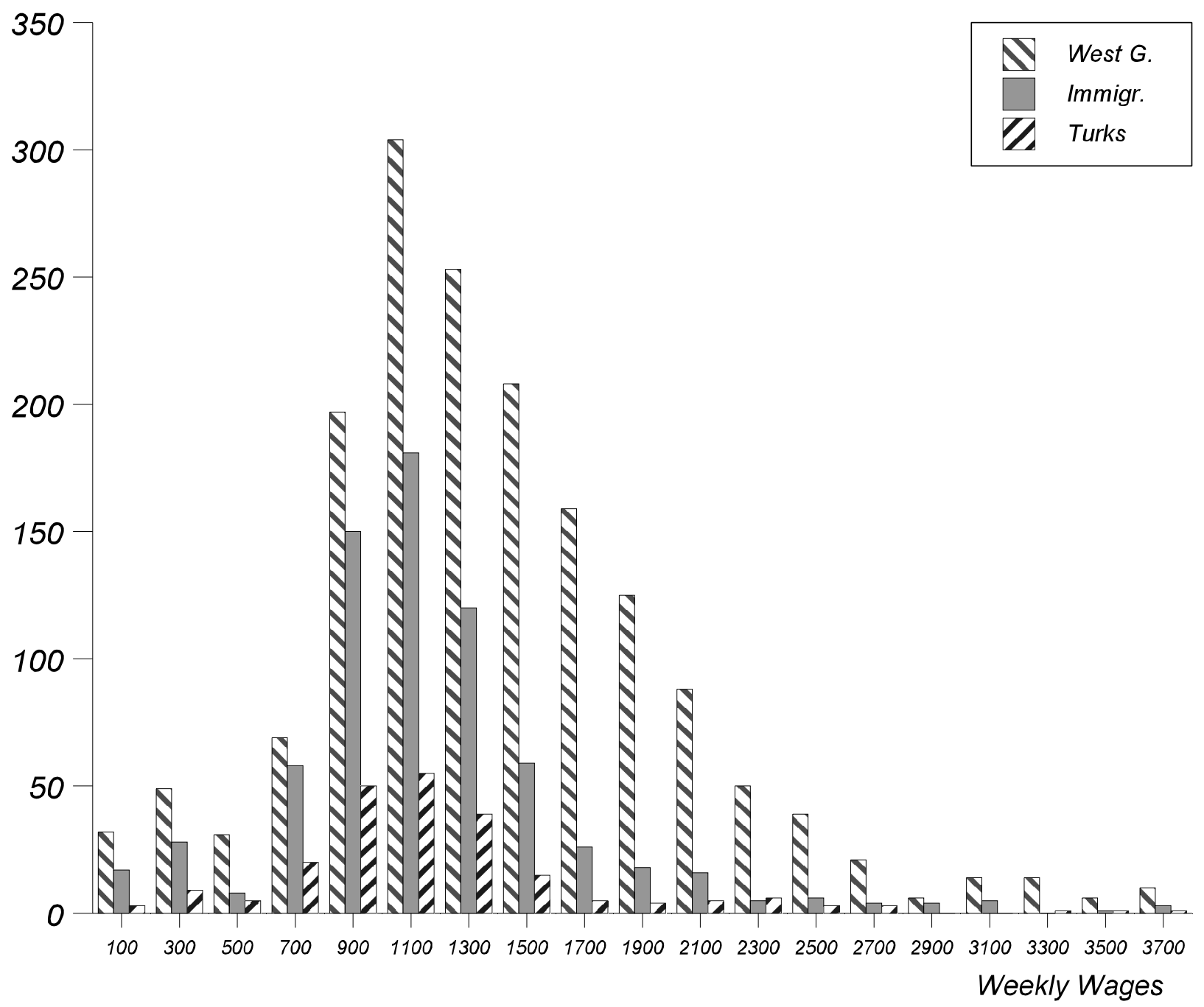

Figure 1: Wage Distributions of Men in Germany 